\title{
Research on construction techniques of the "genoese" coastal towers in southern Corsica (built between XVI and XVII century)
} Paola Rita Altamura

University of Florence, Florence, Italy, paola.mura.2013@gmail.com

\begin{abstract}
The research comes from the study of techniques adopted in the building of the coastal towers on the island of Corsica between XVI and XVII century. The research is structured in a first phase of acquisition of the archival material, historical-iconographic, bibliographic and cartographic and then developed in the direct study of the artifacts and leads through instrumental relief and photographic documentation, stratigraphic analysis and the investigation of building materials.. All the material has been prepared for the graphical restitution of the complete volumes of the towers, and compared with the rich archival documentation of scale models of the towers and of the metrical estimate calculations. The archival research and surveys in the site led to the identification and recognition about the artefacts, in particular about those reduced to ruins, of the construction techniques on the masonry, quality and utilitazion of mortars, quality and use of bricks and of the stone material, particular technique of "opus gallicum" for reinforcement of the vaults.
\end{abstract}

Keywords: coastal defense, construction techniques, interpretation of documents, master masons.

\section{Introduction}

The research examines the system of coastal towers of Corsica built during the rule of the Repubblica of Genova, in the time when it took over the administration after the sale by Banco of San Giorgio which took place in 1562 and until the final moving to France which took place in 1768. The towers built in the period of time from sixteenth early seventeenth century are properly referred to as "genovesi".

In the structure geo-politics of the Mediterranean, the Corsica has been always the keystone of the eastern Mediterranean. This has been in the forefront of the war waged by the barbary pirates along with Sardegna and became a bulwark against the leading of the Ottoman Empire especially in the sixteenth century. Hence the urgent need to provide the island with a tight defensive system static, consisting of the coastal watch-towers which were also helpful as the preservation of productive activities coastal island. These towers were essential for the safety of coastal populations and for the support of the fortified cities through optical links, and those cities which were reserved for an active defense.

The research presented here was born and developed in view of the hearings of the historical-construction of towers coast of the island of Corsica in the genoese dominion.

The first phase of research is structured in a preliminary acquisition of such materials as: library materials, historical, iconographic (current and time) and archival.

The archival research was conducted at the Archivio storico of Genova, it has a rich documentation and a special Fondo Corsica separate from other and including all documents 
concerning officials, administration, justice, economy and planning related to the island.

The Fondo also has a section called Turrium that collects a large corpus of these parchments the extensive correspondence between the Magistrato of Corsica and the Serenissima Repubblica, decorated with drawings of the towers, technical documents and preconstruction estimate for the construction of the towers. The archival research and survey in situ led to the identification and recognition of the artifacts, especially of those reduced to ruins, manufacturing techniques on the walls, quality and use of mortars, quality and use of brick and stone material, unusual techniques "opus gallicum" for the reinforcement of the vaults.

The next stage was the preliminary analysis of the coastal system of Corsica's towers, then focus on two towers investigated more detailed knowledge: the Sponsaglia and Sant'Amanza towers, studied through photographic survey and reconnaissance of the site.. The material collected has led to the development of data sheets on the individual artifacts and produced synthesis typological's studies about the coastal fortified system.

The two towers have also been the subject of systematic study of the site and of the manufacture, acquisition of information through photographical survey, sampling of materials/structures and poll of the conservation status. Also, since there were many collapsed parts the two towers were reveal and cataloged. All captured material was developed for the graphics layout of tower's complete volumes and of masonry's collapsed parts.

Useful for the study and the graphic rendition of the towers' volumes were use new graphic program. This program combines the spherical photogrammetry algorithms of image-based modeling.

For processing the synthesis's results it was compared the cognitive survey about materials with the documentary materials which contained scale models of the towers and bill of quantities. The archival materials were interpreted through the study of the "language in the site" in use between five hundred and six hundred in Genova (Decri, 2009). Infact the workers were almost exclusively imported from Genova, and from this language were extrapolated the manufacturing practice about the building and the maintenance.

\section{The archival research: the Fondo Corsica}

Archival research took place in the Archivio di Stato of Genova and it was focused primarily on the Fondo Corsica and specifically on the subsection "Turrium", composed of countless strings cataloged and each containing loose sheets of parchment. This consultation aimed to find out about planning and tecnological aspects used in the construction of the towers, and material graphic design. The language is Italian in use between five hundred and six hundred, latin and rarely also the greek. The strings take up the correspondence between the Repubblica of Genova and the Magistrati of Corsica (Salone-Amalberti, 1992) Ever since 1510 the Banco of San Giorgio had raised the issue of the need to provide the island with a fortification system that somehow arginasse desertification of coastal areas. In 1531 he was elected, by the same Banco, a Commissario Generale which could draw up a defense's plan and gave start to the first series of buildings, within a system of concessions to the inhabitants of the places and through the imposition of a salt tax (Graziani, 1992). Under the Banco of San Giorgio's administration will be built 25 towers, most of which around Cap Corse. It is the $27^{\text {th }}$ november 1571, when the Senato genovese approves a law on the election of a special magistrate, the "Magistrato delle semine e della Fabbrica delle Torri" consists of four works, came with the decision by the officials genoese who will have the task of providing the commercial control (fishing coral, mineral extraction) and political organization of the island but principally of coastal defence through the construction of watchtowers with attack-defence function and their maintenance (Graziani, 1992) Infact, the need to provide the island with fortifications, roads, bridges, port facilities, like priority Repubblica of Genova to adopt an interventionist policy and not just defensive. 
Therefore the towers' construction program is preceded by an important reconnaissance of the island completed by two special magistrates: Cristoforo Fornari and Francesco di Nigro, who with an inspection study, along the coast of the island draw up a list (ASG, Fondo Corsica, Filza $\mathrm{n}^{\circ}$ 885) of all the headlands and beaches strategically suitable to the construction of the towers. This inspection will be the basis for the drafting of a towers' list "to be built", accompanied by place names and visually relief of the headlands reported in interesting "portraits".

As stated in the string 885 (Graziani, 1992), dated $25^{\text {th }}$ June 1573 , the two commissioners sent the report of the reconnaissance, which shows the places that require the construction of several towers ex novo, and the annotation of existing towers including fortified cities and the towers from complete or heal in relation to the state. The result will be a list of 100 towers of which 65 will be newly built (Serpentini, 2008).

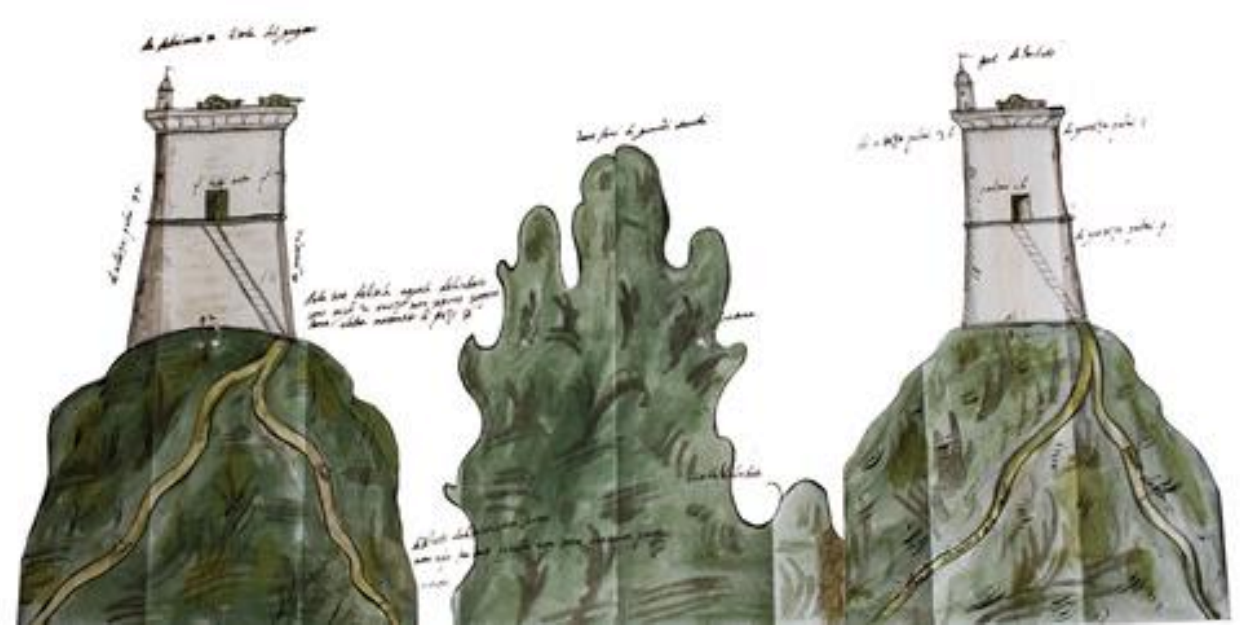

Fig. 1- Tower Galgano and of the Imbuto (A.S.G. Fondo Corsica, Filza 538)

\subsection{Bill of quantities and dimensioned drawings}

The first archive text which refers about the construction of the coastal towers, under the Repubblica of Genova (as mentioned previously) is dated 1573 (ASG, Fondo Corsica, Filza $n^{\circ} 885$ ). In this text is read that the towers will encircle the entire island for defense against "infidels". The Repubblica of Genova will also accord lands for towers' construction.

The construction generally is preceded by an inspection to the geographical location, and by a report related drawings of geographical indications of the tower and its rough dimensional.

The supply of equipment related to the tower erection was done preferably by sea to the beach closest to the place where to build. Here were brought mortar (usually from Bonifacio, Ajaccio, Bastia), water and munitions for the guards required to protect them, while the sand was taken directly from the beach landing. Land transportation then was done by men or women's hand or on horseback.

The start order of the yard was then accompanied by a preliminary report, prepared by the commissioner who would have to supervise the construction's factory, prepare the site and the bill of material with prescription on the quantity and quality and sizing structure. The report also contained detailed spending and ended with the representation of the layout size of the tower or towers to be built, the master mason. 
The drawings are colored ink on parchment and placed in the environment, with numerous annotations dimensional; sometimes in the drawing it is inserted location of all the elements attached as tank, furnace, etc rivellino. The scale used, when inserted, is in tenths of a palm genoese, ie ca. 0,248 (Rocca, 1871).

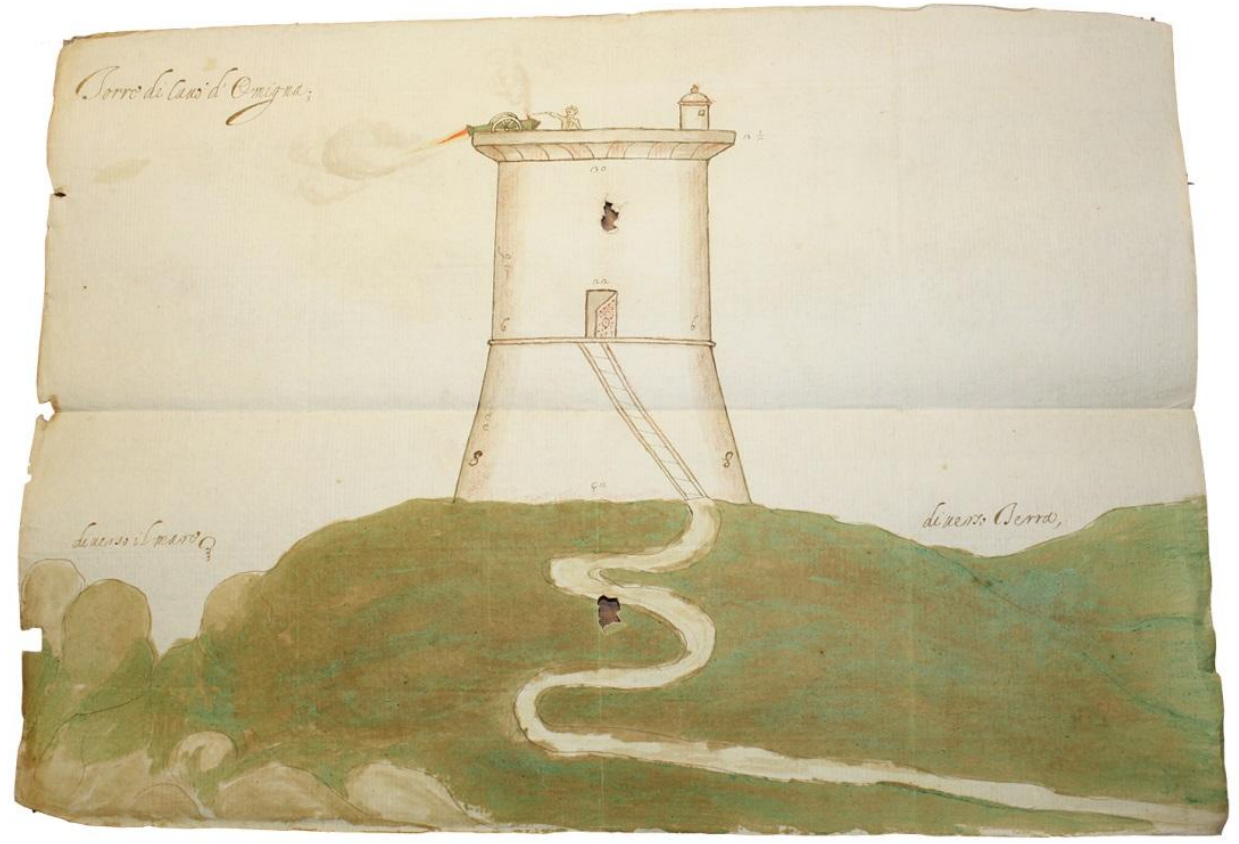

Fig. 2- Tower ofi Omigna (A.S.G., Fondo Corsica, Filza 886)

\subsection{The metric-photogrammetric survey}

The relief phase was preceded by a first general reconnaissance exploration around whole system of the towers of the island, visiting the towns of Bonifacio, Ajaccio, Calvi, Bastia, Porto Vecchio, St-Florent.

This finding study produced a large corpus of photographic material, followed by specific inspections, of greater depth, that have limited the area of the towers examined The towers of Sponsaglia and Sant'Amanza, located in the south-east of the island, have been chosen as subject of study.

These two towers, although being in ruins and without the cylindrical volume higher, had not undergone renovations or restorations as observed in the volumes or documented through literature sources.
The two buildings' relief has presented many difficulties for the geometric characteristics of the two volumes and for the difficulties to access the site.

The instruments used are classical instrumental metric relief.

All elements collapsed nearby the towers were detected and cataloged. All the masonry's external samples were photographed with metric framework and level.

The thicknesses of mortar and joints were measured. All the masonry samples were then processed through the program RDF.

Infact the masonry's portions, relatively small extended and in which the 'angle of curvature is not appreciable, can be approximated to flat surfaces. 


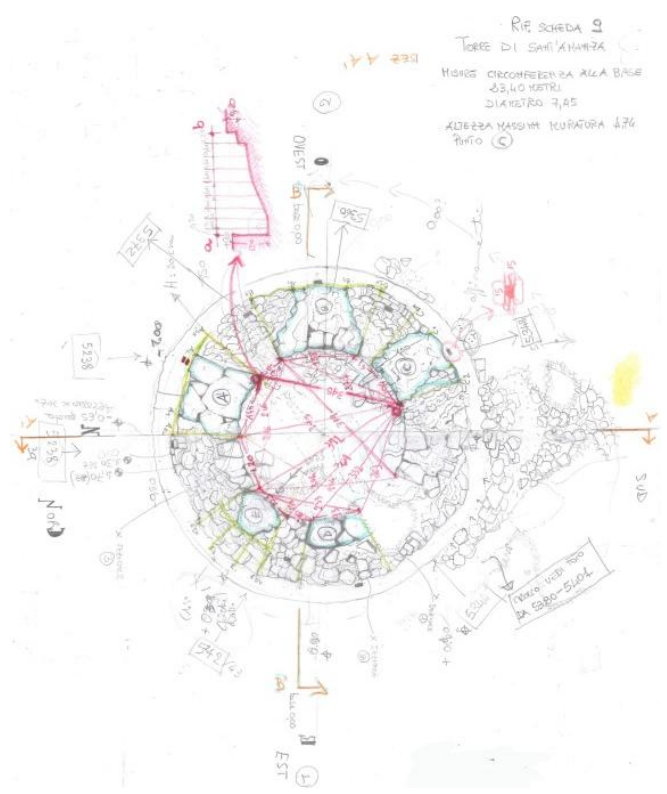

Fig. 3- Sant'Amanza tower's study sketches.The tower's upper walls sections was reliefed by section survey. (Marino, 1990).

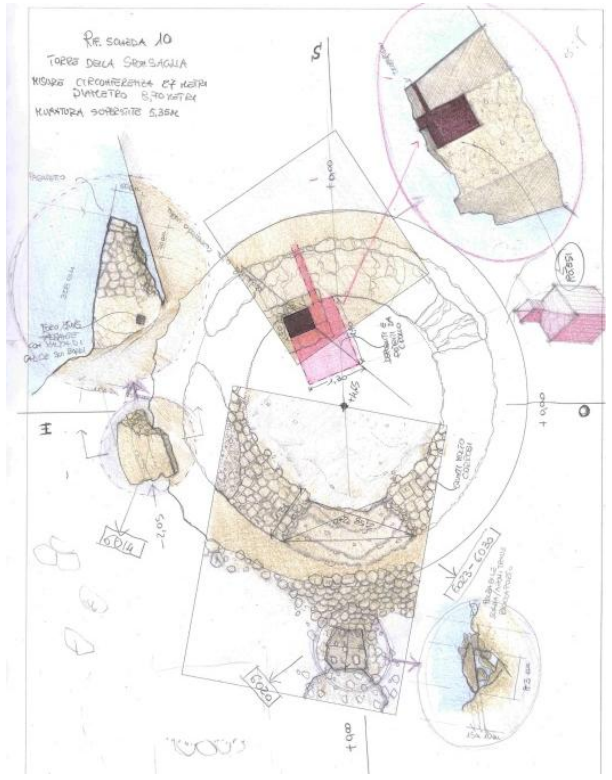

Fig.4- Studies prominent tower Sponsaglia

For the measuring volume's Santa Manza tower, new image- matching's graphics tools were used. Specifically, the software used is the 123D Catch. It produces surfaces mesh from a sequence of photos taken according to very simple criteria. The mesh obtained, subsequently, should be oriented and scaled in the virtual space using a 3D modeling software, to obtain a usable and measurable model based on algorithms of SFM. The program works on photographic marker applied to the structure. It is valid for photographic surveys in scale 1: 100, with a margin of error that is part of the " graficism error " (Casu-Pisu, 2013).

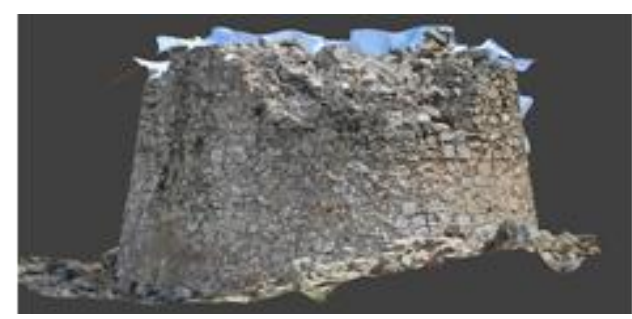

Fig. 5- Sant'Amanza tower's prospectus northwestern (re-elaborate Blender program)

The tower Sponsaglia is located near Bonifacio's town, in places Suartone, and stands on the promontory's top of Sponsaglia, in the most extreme part of the south-east's island. The promontory's altitude is $53 \mathrm{~m}$ above sea level. In the tower's south-west area there is a rectangular rivellino of modest size The surviving part of the tower is the base truncated cone diameter of $870 \mathrm{~cm}$ and survivor masonry's height is $525 \mathrm{~cm}$. The foundation rests directly on granite rock. A small rectangular tank is lodged in the tower's basement, barrel vault. The width size is $160 \mathrm{~cm}$ $\mathrm{x} 130 \mathrm{~cm}$ and $295 \mathrm{~cm}$. height. The size perimeter's wall is $125-130 \mathrm{~cm}$, composed of local various sizes stone. Except some detachments, the wall surface is almost completely plastered. The tower Sant'Amanza is located in the town of Bonifacio, and is situated at top of promontory in the Golfo of Sant'Amanza, in the south-east of the island. The promontory's altitude is 108 meters above sea level. It has been also categorized as small watchtower. The plant is circular. The circular plant's circumference is $234 \mathrm{~cm}$, diameter $745 \mathrm{~cm}$ and existing masonry's maximum height of the base section is $474 \mathrm{~cm}$.

The masonry is set directly on the rock outcrops and the foundation is absent. The perimeter masonry is manufactured by many big ashlars 
blocks placed on almost regular basis, mostly totally exposed and thickness $135-140 \mathrm{~cm}$ ca. On almost the total tower's perimeter are visible scaffolding holes, their size is $15 \times 15 \mathrm{~cm}$ ca.

\section{Conclusions}

The two towers, object of systematic study, are classified as small whatchtowers, built in the first decades of the XVIIsecolo, designed by master builder Taddeo Cantone. The return of volumes and analysis perlustrativa around the island's coastal system underlines that the most common typological form genoese tower typological is a circular base of a truncated cone slope topped by cylindrical volume and whit a curb reconciliation between the two volumes. The towers culminate in a continuous or punctual parapet or coping, interspersed with trap doors and completed by a sentry. A small percentage towers are square base, these are most characteristic of the north island. The origins of the circular pattern is to be charged almost exclusively to its simple construction and therefore cost much less than a square equivalent surface. Without sharp edges, of laborious processing, the round tower offers in addition to the ease and rapidity of raising a remarkable structural strength both to static stress as especially those dynamics consisting of the possible impacts of projectiles and in kickback of the guns. The typology deduced from the thecnical documents, from dimensioned archive drawings and from reliefs in situ is a structure on three levels In the basis volume's level are placed the tank and warehouses, the median is used as accommodation of the garrison, the parade ground is on the top level. The two floors were coverei with barrel vault and the second level was connected to the terrace through a wood, stone or matter staircase built inside the tower's masonry The pavement of the first floor above the glove rested below flared filled with stones, lime and soil (a kind of embankment) in which was housed the compartment for the tank of rectangular shape, or sometimes even square. The tank's wall, to withstand the water pressure and maintain watertight, were thick until a meter. Inside was covered with a bandage less porous bricks. The whole compartment was sealed with a coating of earthenware. The external volume consists of brick faced wall, the masonry is internally straight and external flared, with a conglomerate link inside, between the two walls, consisting of lime mortar and rubble. The floor area was covered with a barrel or semi-spherical vault and made of brick or stone and mortar. The tower's height made it inviolable. The inlet was located 5/6 meters above the ground. It was an expedient found in all towers. For entry was used then a ladder, retractable or, if fixed, with a small drawbridge. This simple trick is probably inherited from the Middle Ages. The material, used in Sponsaglia and Sant'Amanza towers, for the construction of the building depended locally available lithotype. Since the area formed exclusively by granite outcrops the two artifacts are made from granite blocks of various sizes.
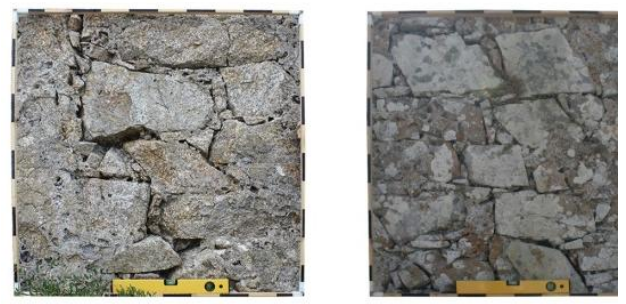

Fig. 6- masonry's samples of Sponsaglia and Sant'Amanza towers.

The blocks set in place were left in their raw state filling) rather than by the failure of the stone itself. The weak point is cohesion rather than their intrinsic resistance. Two large pieces of masonry, from the collapse of the original cylindrical volume, are placed at the Sponsaglia's foot and in proximity of the slope at10 meters ca. of distance. These two imposing pieces of masonry presents singular holes, which extend longitudinally inside the dividing wall and at the point in which it would set the base of the vault of the compartment space, of similar size, $15 \times 15 \mathrm{~cm} . c a .$. These holes inside have obvious residues of material, at first sight wooden, which is consolidated in the structure of the hole.or processed in "gap". They employed stabilization wedges, binders based on lime and a possible external plastering of 2-3 centimeters. The intrinsic resistance of the material is largely 
underused or mishandled in construction The masonry's breakage or cracking was generally a result of a weakening of cohesion between the constituent elements (mortar, wedges, blocks,

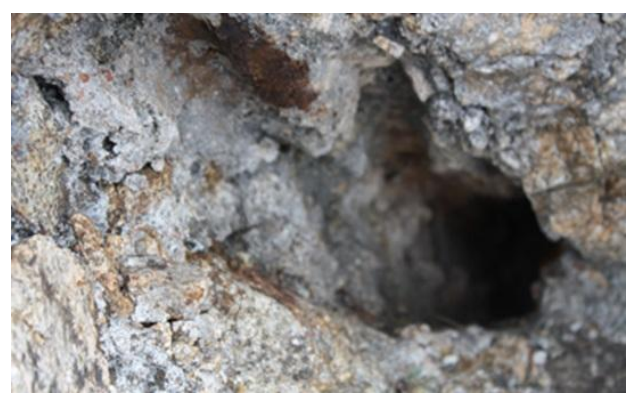

Fig. 7 -One- collapse piece Sponsaglia tower's

The subsequent analysis of the samples established that these are residues ferrous fossilized.

The technical documents tell us that the vaults, in most cases, were distinguished in reading vaults form with brick stone and mortar (sometimes also known as reinforcement, nails and master key workers) or made of matter.
This was a conglomerate of stones and mortar with the insertion of iron hoops or iron chains to counteract the horizontal thrusts. These special design features we bring to mind the unique construction technique of "opus gallicum ", ie the amazing wall unit described by Giulio Cesare about the siege of Avaricum in $52 \mathrm{BC}$, where it was recommended for the military works to include oak beams in the walls in order to cushion the blows and to facilitate the inevitable repair works (Marino, 2011).

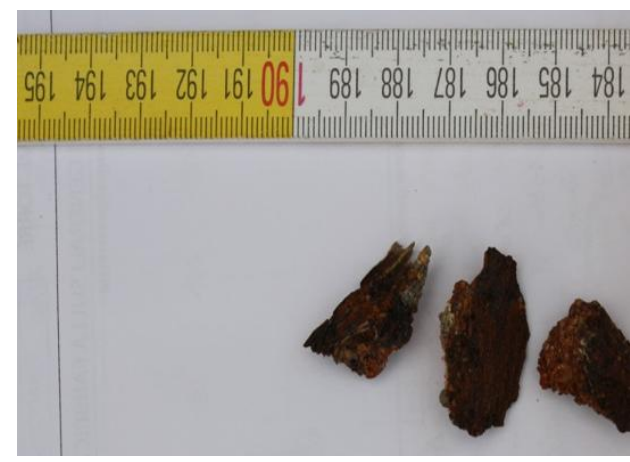

Fig. 8- Through hole's residues ferrous of fig.7

\section{References}

Casu P., Pisu C. (2013) "Cloud GIS and 3D Modelling" (Atti del convegno International Archives of the Photogrammetry, Remote Sensing and Spatial Information Sciences, Strasburgo, p. 490.

Casu P. (2011-2012) Tesi di dottorato di ricerca in tecnologie per la conservazione del beni architetionici e ambientali, Cagliari, pp. 121-126.

Chiovelli R. (2007) “Tecniche costruttive murarie medievali”, L'Erma di Bretschneider, Roma, pp. 58120.

Decri A. (2009) "Un cantiere di parole, glossario dell'architettura genovese tra Cinquecento e Seicento" in Archeologia dell'Architettura, All'insegna del Giglio, Borgo S. Lorenzo.

Faglia V. (1974) "La difesa anticorsara in Italia dal XVI secolo: le torri costiere, gli edifici rurali fortificati", in Castella 10, pp. 7-17.

Graziani A. M. (1992) Les tours littorales. Editions Alain Piazzola. Ajaccio, pp. 12-17-21.

Marengo E., Manfroni C., Passagno G. (1911). Il Banco di San Giorgio. Genova.

Marino L. (2011) "La difesa costiera d'epoca crociata nel vicino Oriente. Materiali e tecniche costruttive", in Castellum 52. Roma, p. 14.

Marino L. (1990) ll rilievo per il restauro, Edizione Hoepli. Milano, p. 5.

Marino L.(1970) "La difesa costiera contro i saraceni e la visita del marchese di Celenza in Capitanata", Centro studi e ricerche $\mathrm{n}^{\circ} 6$, Nocera Editore, pp. 7-18.

Meria G. (2004) Tours du littoral du Cap Corse, Ed. Alain Piazzola. Ajaccio, pp. 3-15.

Rocca P. (1871) Pesi e misure antiche di Genova e del genovesato, Genova.

Salone A.M., Amalberti F., La Corse: images et cartographie, Ed. Alain Piazzola. Ajaccio, p. 10.

Serpentini A.L. (2008) “Aspects du sistème défensif de la Corse génoise a l'époque moderne" (Atti del Convegno Contra Moros y Turcos, Baunei 2005), Cagliari, pp. 293-307. 
Stringa P. (1982) Genova e la Liguria nel Mediterraneo, insediamenti e culture urbane, Ed. Sagep. Genova.

A.S.G., Archivio segreto, Filza "Trattati e negoziazioni".

A.S.G., Fondo Corsica, Filza n ${ }^{\circ} 885$; Filza n ${ }^{\circ}$ 886; Filza n ${ }^{\circ} 538$. 